\title{
Drip irrigation provides the salinity control needed for profitable irrigation of tomatoes in the San Joaquin Valley
}

\author{
by Blaine R. Hanson, Don E. May, Jirka \\ Šimunek, Jan W. Hopmans and Robert B. \\ Hutmacher
}

\begin{abstract}
Despite nearly 30 years of research supporting the need for subsurface drainage-water disposal facilities, the lack of these facilities continues to
\end{abstract} plague agriculture on the San Joaquin Valley's west side. One option for coping with the resulting soil salinity and shallow water-table problems is to convert from furrow or sprinkle irrigation to drip irrigation. Commercial field studies showed that subsurface drip systems can be highly profitable for growing processing tomatoes in the San Joaquin Valley, provided that the leaching fraction can achieve adequate salinity control in the root zone. Computer simulations of water and salt movement showed localized leaching fractions of about $25 \%$ under subsurface drip irrigation, when water applications equaled the potential crop evapotranspiration. This research suggests that subsurface drip irrigation can be successfully used in commercial fields without increasing root-zone soil salinity, potentially eliminating the need for subsurface drainage-water disposal facilities.

\footnotetext{
7 he lack of widespread subsurface

1 drainage-water disposal facilities continues to plague agriculture along the west side of the San Joaquin Valley. Despite more than 30 years of research, drainage-water disposal methods that are economically, technically, politically and environmentally feasible have not been implemented. In some areas, land retirement has been the result.
}

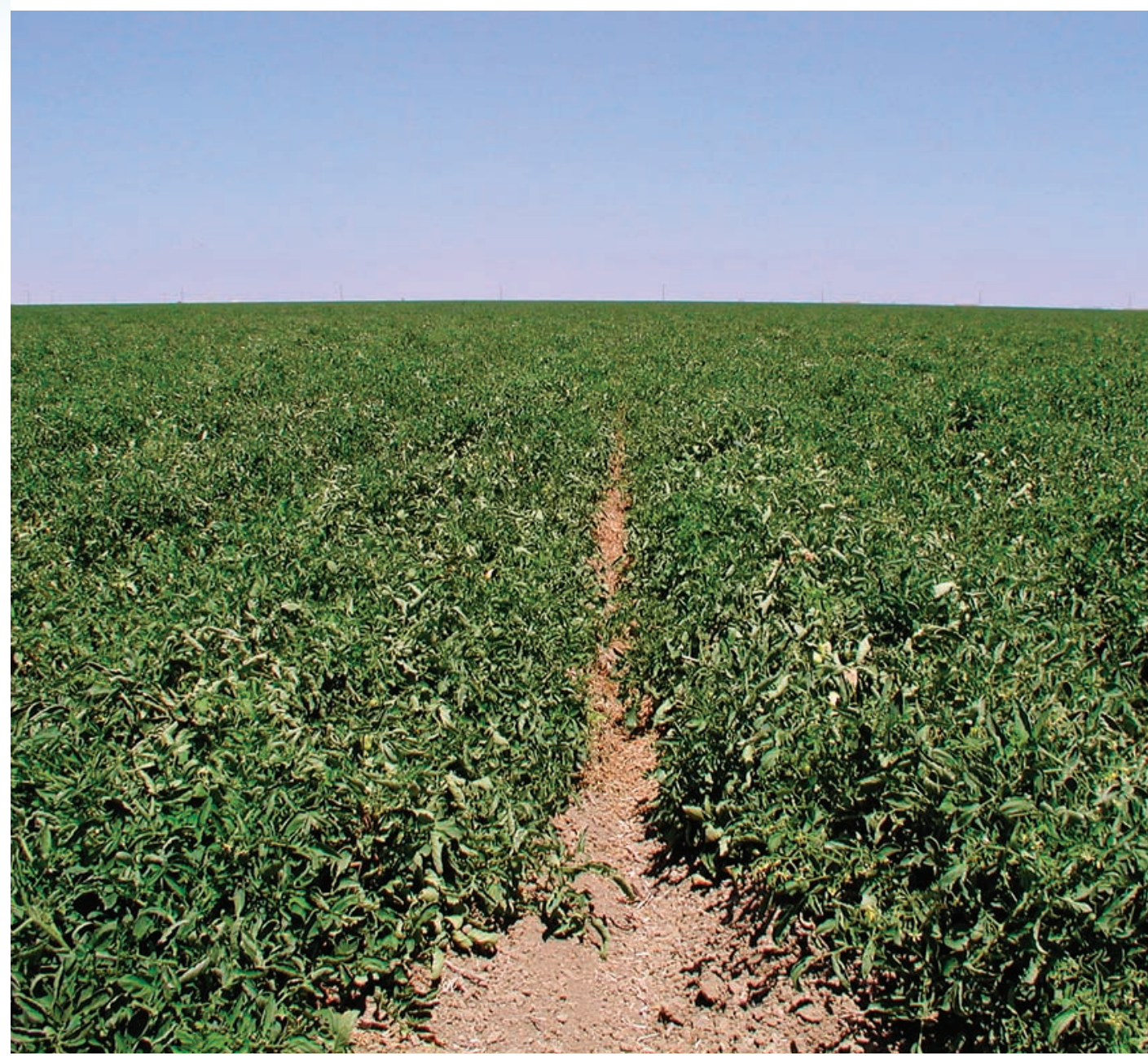

Subsurface drip irrigation is allowing San Joaquin Valley tomato growers to apply water precisely and uniformly, increasing yields and reducing the runoff of saline drainage water.

A UC study (Schoups et al. 2005) concluded that a salt balance must be maintained in the root zone for productive cropping systems to continue, and irrigation without improved management practices cannot be sustained in the San Joaquin Valley. The only options available to address salinity and drainage problems without retiring land are: (1) reducing drainage through the better management of irrigation water; (2) increasing the use of shallow groundwater for crop irrigation without any yield reductions; and (3) reusing drainage water. All three methods require adequate salinity control in the root zone. This study is an example of the first option; as a result, subsurface drip irrigation is commonly used in salt-affected soils for processing tomato production. The second option has been proposed, but little information exists on its use by growers. The California Department of Water Resources is promoting the third option, but its use is limited and still in an experimental stage.

One way to implement option one is to convert from furrow or sprinkle irrigation to drip irrigation. Drip irrigation applies water precisely and uniformly at high frequencies, potentially increasing yield and reducing root-zone soil salinity and drainage. These advantages are not only governed by the technology, but also by the design, installation, opera- 


\section{Subsurface drainage systems and drainage-water disposal methods are not needed for properly designed and managed drip irrigation systems.}

tion and maintenance of drip systems. The main disadvantage of drip irrigation is its high installation cost, which ranges from $\$ 600$ to $\$ 1,000$ per acre. Subsurface drip irrigation, commonly used for processing tomatoes, involves placing drip lines 8 to 12 inches below the soil surface directly below the plant row; surface drip irrigation involves placing the drip lines on the soil surface.

In the late 1980s, two large-scale comparisons of subsurface drip and furrow irrigation were conducted in cotton under saline, shallow groundwater conditions (Fulton et al. 1991; Styles et al. 1997). Drip irrigation consistently resulted in higher cotton yields with less water application than furrow irrigation. However, the profit with furrow irrigation was much higher at one location, and drip irrigation was only slightly more profitable at the other. The cost of the drip systems played the major role in their profitability. As a result, growers who convert to drip ir-

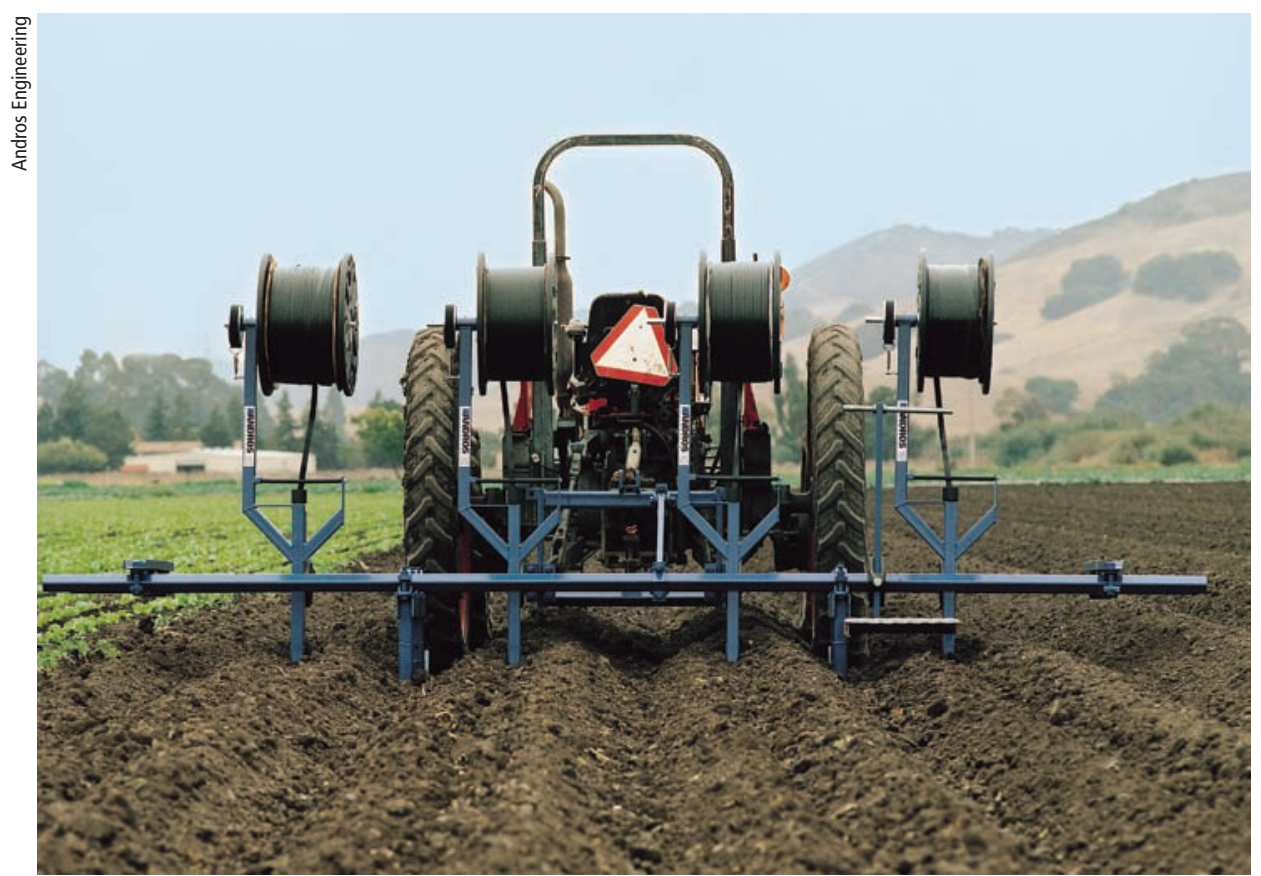

Specialized equipment (shown here, by Andros Engineering) is used to install drip tape 8 to 12 inches below the soil surface, at a cost of about $\$ 600$ to $\$ 1,000$ per acre. Despite this price, studies show that improved irrigation efficiency and yield benefits increase profits for growers in the San Joaquin Valley, compared with sprinkle or furrow irrigation.
Between 1998 and 2003, experiments in commercial fields in the Westlands Water District, on the San Joaquin Valley's west side, evaluated subsurface drip irrigation of processing tomatoes under saline, shallow groundwater conditions. In addition, starting in 2006, computer simulations using the HYDRUS-2D model (Šimůnek et al. 1999) evaluated leaching with subsurface drip irrigation under these conditions. This model has been used previously in studies of water and chemical movement under drip irrigation (Gärdenäs et al. 2005; Hanson, Šimůnek, et al. 2006). We present a review of this research.

\section{Commercial field experiments}

Experiments in three commercial fields (sites BR, DI and DE) compared subsurface drip irrigation to sprinkle irrigation (Hanson and May 2003, 2004). Drip systems ranged from 40 to 80 acres each in area, and sprinkle irrigation was used for the rest of the fields. Water table depths ranged from 2 to 6 feet. Electrical conductivity ranged from $0.3 \mathrm{dS} / \mathrm{m}$ for irrigation water from Westlands Water District to $1.1 \mathrm{dS} / \mathrm{m}$ for well water, and from 4.0 to $16.4 \mathrm{dS} / \mathrm{m}$ in the shallow groundwater. A small-scale, randomized, replicated experiment was conducted in each drip-irrigated field to investigate the relationship between yield, soluble solids (a measure of yield quality) and applied water. The soil type was clay loam at the three experimental sites.

We found that subsurface drip irrigation was highly profitable for processing tomatoes under these shallow, saline groundwater conditions compared to sprinkle irrigation. Average yields were 40.5 tons per acre for subsurface drip irrigation versus 33.9 tons per acre for sprinkle irrigation, with $\$ 484$ per acre more profit on average for drip than sprinkle irrigation. The average difference in soluble solids between the two irrigation methods was not significant. The small-scale experiments showed increased yield and decreased soluble solids as applied water increased.

Yields of the drip-irrigated fields were monitored for 2 more years after 
the first year. Yields remained high except for one site, which had 2 years of reduced yields due to late plantings. We did not find any trends toward yield reductions with increased soil salinity near the drip lines, which ranged from values less than, to higher than, the threshold electrical conductivity of 2.5 $\mathrm{dS} / \mathrm{m}$ for tomatoes.

At a fourth commercial field (site BR2), a small-scale, randomized-block, replicated experiment evaluated the response of tomato and cotton yields to different amounts of applied water under very shallow groundwater conditions of 18 to 24 inches (Hanson, Hutmacher, et al. 2006). The soil type was clay loam. Tomato yields ranged from 34.6 tons per acre for 15.6 inches of applied water to 42.8 tons per acre for 23.2 inches, even though nearsaturated, highly saline soil occurred at only 18 inches deep. At 23.2 inches, water application is about equal to the seasonal evapotranspiration or crop water use for tomatoes. However, cotton yields did not respond when water was applied at amounts equal to or greater than about $40 \%$ of the potential seasonal evapotranspiration. The electrical conductivity of the irrigation water was $0.5 \mathrm{dS} / \mathrm{m}$ and of the ground-

TABLE 1. Seasonal applied water,
evapotranspiration and leaching fractions
calculated from a water balance for four
commercial sites

water was 8 to $10 \mathrm{dS} / \mathrm{m}$ (the threshold for cotton is $7.7 \mathrm{dS} / \mathrm{m}$ ).

At all commercial sites, tomato yields increased as applied water increased. Factors contributing to this finding included higher soil-water content and reduced root-zone soil salinity due to larger zones of low salt around the drip lines as more water was applied. Cotton yields, however, were unresponsive to the amount of applied water, reflecting cotton's salt tolerance and ability to utilize saline, shallow groundwater (Wallender et al. 1979). Consequently, contributions by the saline, shallow groundwater to crop evapotranspiration should be minimized for tomato and maximized for cotton.

Soil salinity levels around the drip lines depended on the depth to groundwater, salinity of shallow groundwater, salinity of irrigation water and amount of applied water. For a water table depth of about 6 feet, relatively uniform soil salinity occurred throughout the profile, with values smaller than the threshold electrical conductivity of tomato (fig. 1A). For water table depths less than about 3 feet, relatively low levels of soil salinity occurred near the drip line, but values increased to high levels beyond the wetting pattern due to the upward flow of shallow groundwater (figs. 1B and 1C). Higher soil salinity occurred near the drip line when the salinity of the irrigation water increased (fig. 1C). Larger amounts of applied water increased the zone of low-salt soil near the drip line, even when shallow water tables had depths of less than 2 feet (fig. 2).

At all sites, water table depth showed little response to drip irrigation, except when overirrigation occurred during one year at site BR (data not shown). A subsequent reduction in applied water at that site caused the water table to decline due to reduced percolation and the natural drainage of shallow groundwater.

\section{Determining leaching fractions}

Salinity control is needed in the root zone to maintain profitable subsurface drip irrigation of tomatoes in salt-affected soils. This can be achieved by leaching or flushing salts from the

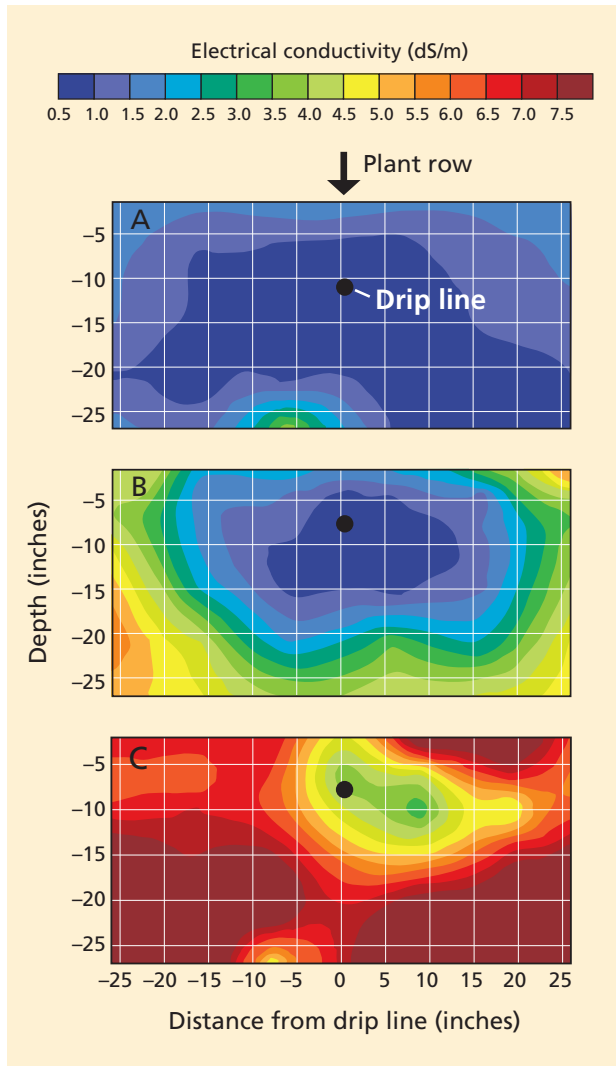

Fig. 1. Soil salinity/electrical conductivity (EC) around the drip line for water depth of about (A) 6 feet, EC irrigation water $=0.3 \mathrm{dS} / \mathrm{m}, \mathrm{EC}$ groundwater $=8$ to $11 \mathrm{dS} / \mathrm{m}$; (B) 2 to 3 feet, EC irrigation water $=0.3 \mathrm{dS} / \mathrm{m}, \mathrm{EC}$ ground water $=5$ to $7 \mathrm{dS} / \mathrm{m}$; and (C) 2 to 3 feet, EC irrigation water $=1.1 \mathrm{dS} / \mathrm{m}, \mathrm{EC}$ groundwater $=9$ to $16 \mathrm{dS} / \mathrm{m}$.

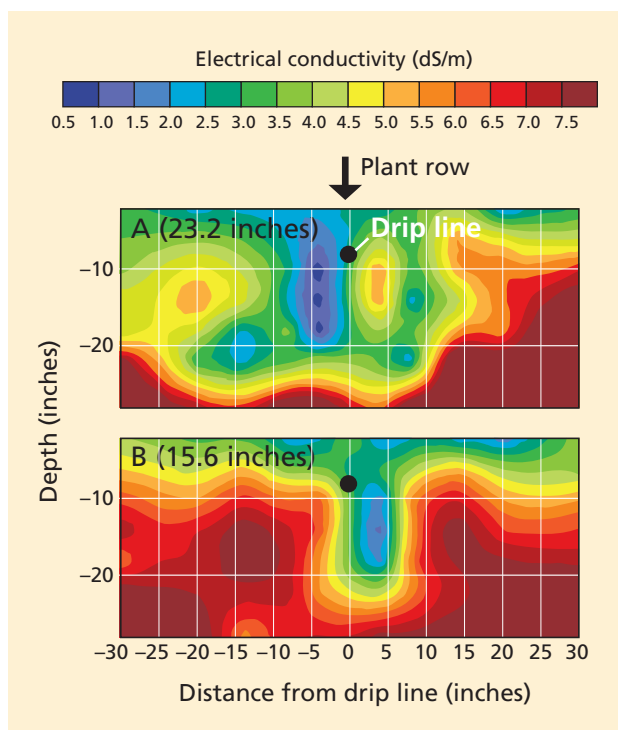

Fig. 2. Soil salinity/electrical conductivity (EC) around the drip line for water depth of about 18 to 24 inches, EC irrigation water $=0.5 \mathrm{dS} / \mathrm{m}$, EC groundwater $=8$ to $10 \mathrm{dS} / \mathrm{m}$, for water applications of (A) 23.2 and (B) 15.6 inches. 


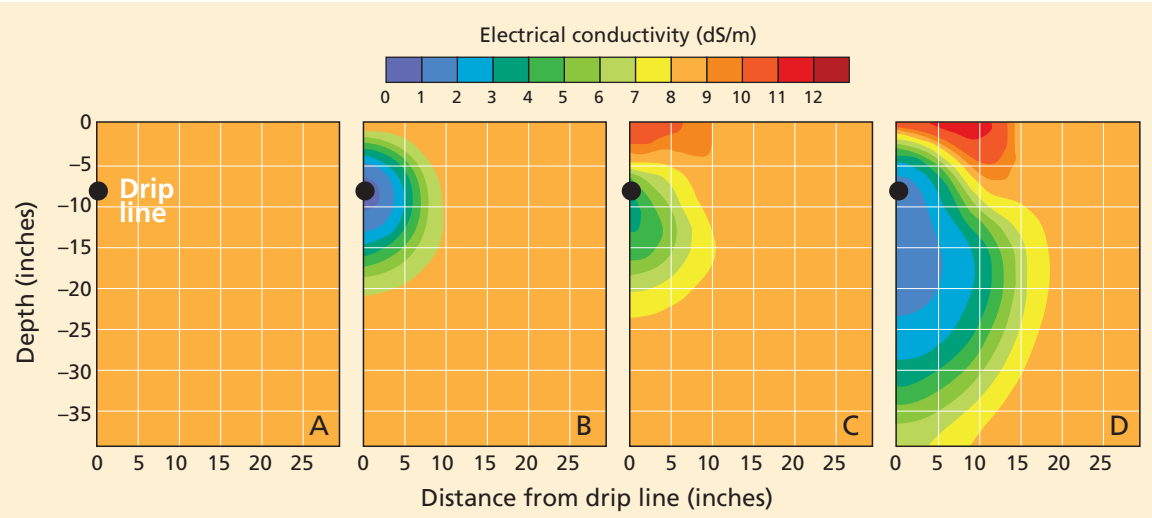

Fig. 3. Soil-water salinity/electrical conductivity (EC) around the drip lines at (A) start of simulation period ( $T=0$ day), (B) just after first irrigation ( $T=1$ day), (C) just before second irrigation ( $T=3.5$ days) and $(D)$ just after last irrigation $(T=39.5$ days). Applied water $=100 \%$ evapotranspiration; EC irrigation water $=0.3 \mathrm{dS} / \mathrm{m}$.

root zone - applying irrigation water in amounts exceeding the soil moisture depletion. The leaching fraction is used to quantify leaching adequacy, and is derived from the ratio of the amount of water that drains below the root zone to the amount of water applied.

Leaching fractions can be determined several ways. One approach is to measure the average salinity of the root-zone soil and irrigation water, and then use appropriate charts or equations to determine the leaching fraction. However, soil salinity, soil-water content and root density all vary around the drip line, resulting in uncertainty about the accuracy of root-zone soil salinity.

A second approach commonly used is the water balance method, by which a fieldwide amount of leaching is calculated as the difference between the seasonal amount of applied water (measured with a flow meter) and evapotranspiration. Because actual evapotranspiration in a given field is usually unknown, it is frequently estimated using crop coefficients and a reference crop evapotranspiration value obtained from the California Irrigation Management Information System (CIMIS).

We calculated fieldwide leaching fractions for the commercial fields using the water balance method. Evapotranspiration was determined using canopy growth rates and a calibrated computer model. These calculations showed little or no fieldwide leaching at most of the sites (table 1), which suggests inadequate salinity control and raises questions about how long drip irrigation can be sustained under saline, shallow groundwater conditions. The soil salinity data, however, clearly showed that because of the wetting pattern under drip irrigation, leaching was highly concentrated near the drip line (referred to as "localized leaching"). The soil salinity data also indicated that the water balance approach is not appropriate for drip irrigation and that estimating actual or localized leaching fractions under drip irrigation may be difficult and also inaccurate. It is reasonable to expect that the salinity patterns reflect long-term behavior, as long as adequate salinity-control measures (sufficient leaching and no groundwater intrusion into the root zone) prevent salts from accumulating in the root zone.

\section{Computer simulations}

Because of the difficulties in estimating actual leaching fractions for the drip-irrigated commercial fields, we used the computer model HYDRUS-2D (Šimůnek et al. 1999) to simulate the movement of water and salt in soil under drip irrigation for a 42-day period and quantify drainage below the root zone. Simulations were conducted for water table depths of 20 and 40 inches; irrigation water salinities of $0.3,1.0$ and $2.0 \mathrm{dS} / \mathrm{m}$; and applied water at $80 \%$, $100 \%$ and $115 \%$ of potential evapotranspiration. For $0.3 \mathrm{dS} / \mathrm{m}$ irrigation water, we conducted an additional simulation of applied water at $60 \%$ of potential evapotranspiration. The depth of application per irrigation was based on a daily evapotranspiration rate of 0.29 inches per day, but the actual simulations varied by applied water amounts and irrigation frequency. The application rate was constant during the simulation period for a particular scenario consisting of a water table depth, an irrigation water salinity and an applied water amount.

We simulated two irrigations per week for a 40 -inch water table depth, and daily irrigations for the 20-inch depth. These frequencies reflect those used in the commercial field experiments (Hanson et al. 2003). The drip line was 8 inches deep, and electrical conductivity of the shallow groundwater was 10.0 and $8.0 \mathrm{dS} / \mathrm{m}$ for the 20 - and 40-inch water table depths, respectively, based on measured levels in the commercial fields. The initial soil-water salinity levels at the start of the simulation period were based on samples collected in spring, prior to drip irrigation. The simulated root distribution was based on field data of rooting patterns for drip-irrigated tomatoes at the UC West Side Research and Extension Center (Hanson and May 2007).

Simulated reclamation (salt removal) of soil near the drip line was rapid, and the simulated salinity patterns were consistent with those found in the commercial fields (fig. 3) (Hanson et al. 2008). The simulations predicted that the volume of reclaimed soil would increase over time, with most reclamation occurring below the drip line, and that salts would accumulate near the soil surface. Large seasonal applications of water would increase the zone of lower-salinity soil near the drip lines, consistent with our field data. But the larger amounts would have little effect on the volume of reclaimed soil above the drip line. As expected, salinity near the drip line would increase as irrigation water salinity increased. The root uptake of soil water would decrease as applied water decreased, suggesting the potential for decreased yields with decreasing water applications, as was found in our commercial field data for processing tomatoes.

The actual or localized leaching fractions for the 40-inch water table 
scenarios were $7.7 \%$ for the $60 \%$ water application treatment, $17.3 \%$ for the $80 \%$ treatment, $24.5 \%$ for the $100 \%$ treatment and $30.5 \%$ for the $115 \%$ treatment. As irrigation water salinity increased, the actual leaching fraction increased as a result of reduced root-water uptake. Even for water applications equal to or smaller than $100 \%$ of potential evapotranspiration, drainage occurred below the root zone due to the spatially variable wetting under drip irrigation.

A common assumption is that applying water at amounts equal to $100 \%$ of potential evapotranspiration results in irrigation efficiency of $100 \%$, defined as the ratio of cumulative root-water uptake to applied water. In cases of drip irrigation at $100 \%$ of potential evapotranspiration, little drainage below the root zone is assumed to occur. However, the computer simulations showed that this assumption is not true. Because of spatially varying soilwater wetting around the drip lines, irrigation efficiency was $74.6 \%$ and $69.7 \%$ for the 40- and 20-inch water table scenarios, respectively, with the $100 \%$ water application. Very high irrigation efficiencies occurred only under conditions of severe deficit irrigation.

Because of high-frequency irrigation, the volume of drainage per irrigation was small and drainage was distributed evenly over the irrigation season. As a result, natural subsurface drainage in the commercial fields was sufficient to prevent groundwater intrusion into the root zone.

\section{Leaching and efficient drip systems}

The field research and computer simulation modeling demonstrated that subsurface drip irrigation of processing tomatoes is highly profitable compared to sprinkle or furrow irrigation under saline, shallow groundwater conditions. Tomato yields increased as applied water increased, and cotton yields were unaffected. These tomato yield results suggest that root uptake of saline, shallow groundwater should be minimized to prevent yield reductions, while the cotton yield results indicate that substantial root uptake of the saline groundwater can occur without yield reductions.
In both studies (field experiments and computer simulations), considerable localized leaching occurred around the drip lines, due to the wetting patterns of subsurface drip irrigation. The localized or actual leaching fractions determined from the computer simulations were about $25 \%$ to $30 \%$ for a water application equal to $100 \%$ of potential evapotranspiration.

Under subsurface drip irrigation of processing tomatoes, localized leaching is highly concentrated near the drip line, resulting in relatively low soil-salinity levels in areas where root density is highest. The water balance approach for estimating leaching amounts is inappropriate for drip irrigation because of such localized leaching.

The computer simulations showed that reclamation around drip lines in saline soil would be rapid. Predicted reclamation was faster for relatively infrequent large water applications per irrigation than for smaller applications. The low-salt zone around the drip line

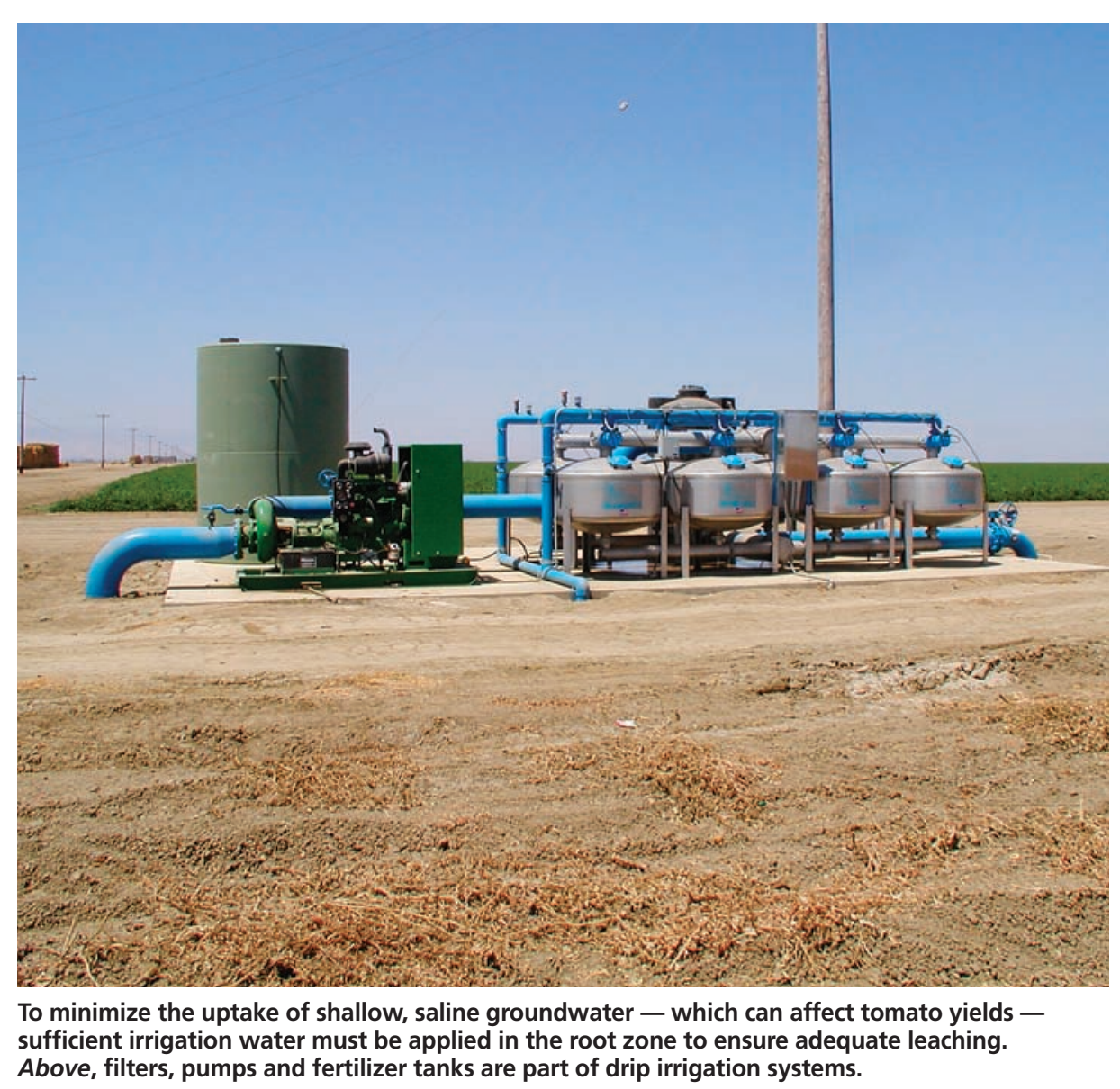

To minimize the uptake of shallow, saline groundwater - which can affect tomato yields sufficient irrigation water must be applied in the root zone to ensure adequate leaching. Above, filters, pumps and fertilizer tanks are part of drip irrigation systems. increased as the amount of applied water increased, and soil salinity around the drip line increased as salinity of the irrigation water increased.

We found that very high irrigation efficiencies under drip irrigation can only be obtained by substantial deficit irrigation, in contrast to the frequent assumption that drip irrigation is nearly $100 \%$ efficient for water applications equal to about $100 \%$ of potential evapotranspiration.

\section{Sustainable drip irrigation}

The key to sustained subsurface drip irrigation of processing tomatoes in salt-affected soils is profitability, which in turn depends on salinity control in the root zone. This requires irrigating with relatively low-salt water; applying sufficient irrigation water for adequate localized leaching; leaching salts that accumulate around the drip line; and preventing saline, shallow groundwater intrusion into the root zone. The following are recommenda- 
tions for subsurface drip irrigation of processing tomatoes under conditions of the San Joaquin Valley's west side:

Water applications. Seasonal water applications should be about equal to the seasonal evapotranspiration, which is 25.5 inches in the San Joaquin Valley (Hanson and May 2006). This provides sufficient localized leaching. Higher applications could raise the water table, causing saline, shallow groundwater intrusion into the root zone. Smaller applications reduce tomato yields.

Salinity of irrigation water. The electrical conductivity of irrigation water should be about $1.0 \mathrm{dS} / \mathrm{m}$ or less; higher levels may reduce yields.

Irrigation frequency. From daily to two or three irrigations per week should occur after the start of drip irrigation (Hanson et al. 2003). Daily irrigations are recommended for very shallow, saline groundwater conditions. The amount of water application per irrigation should be determined using appropriate crop coefficients (Hanson and May 2006) and the reference crop evapotranspiration from CIMIS.

Salt leaching. Periodic leaching of salt accumulated above buried drip lines will be necessary with sprinkle irrigation for stand establishment, if winter and spring rainfall is insufficient.

System maintenance. Drip irrigation systems should be designed for a high uniformity of applied water, and should be properly maintained to prevent emitter clogging.

\section{Drainage-water disposal}

Can drip irrigation eliminate the need for expensive subsurface drainage systems and drainage-water disposal methods? We believe the answer is yes, since no subsurface drainage systems were used at our sites. Subsurface drip irrigation continues to be used at these sites along with many other fields along the San Joaquin Valley's west side.

Drip irrigation resulted in little change to the water table at these sites (except at site BR, where overirrigation occurred), and the computer simulations revealed that drainage or percolation below the root zone would occur. The field data indicated that small ap- plications of water per irrigation and relatively uniform distribution of irrigations over time, coupled with natural subsurface drainage, prevented groundwater intrusion into the root zone. This finding suggests that, for the conditions in these fields, subsurface drainage systems and drainage-water disposal methods are not needed for properly designed and managed drip irrigation systems.

These results indicate that subsurface drip irrigation of processing tomatoes - a higher value, moderately salt-sensitive crop compared to cotton - is sustainable in the salt-affected soils that we studied. Similar results might be expected for crops of similar value that are moderately salt sensitive and suitable for drip irrigation, such as melon. Drip irrigation of salt-tolerant crops such as cotton, sugar beets and grain may not be profitable because of their relatively low cash value. While little research has been conducted in the San Joaquin Valley on drip irrigation of salt-sensitive crops under saline conditions, a literature review of numerous studies on drip irrigation of vegetable crops (Hanson et al. 2008) showed that drip irrigation may be a sustainable practice for salt-sensitive crops.

B.R. Hanson is Irrigation and Drainage Specialist, Department of Land, Air and Water Resources, UC Davis; D.E. May is Farm Advisor Emeritus, UC Cooperative Extension; J. Šimunek is Professor of Soil Physics and Hydrologist, Department of Environmental Sciences, UC Riverside; J.W. Hopmans is Professor of Water Management, Department of Land, Air and Water Resources, UC Davis; and R.B. Hutmacher is Extension Cotton Specialist, Department of Plant Sciences, UC Davis, and Director, UC West Side Research and Extension Center. Support for this project was provided by the UC Prosser Trust Fund; the Westlands Water District; and Farming $D$ and Britz Farming Company, both of Five Points, Calif.

\section{References}

Fulton AE, Oster JD, Hanson BR, et al. 1991 Reducing drain water: Furrow vs. subsurface drip irrigation. Cal Ag 45(2):4-8

Gärdenäs A, Hopmans JW, Hanson BR, Šimủnek J. 2005. Two-dimensional modeling of nitrate leaching for different fertigation strategies under microirrigation. Ag Water Mgt 74:219-42.

Hanson BR, Hutmacher RB, May DM. 2006. Drip irrigation of tomato and cotton under shallow saline groundwater conditions. Irrig Drain Sys 20:155-75.

Hanson BR, May DM. 2003. Drip irrigation increases tomato yields in salt-affected soil of San Joaquin Valley. Cal Ag 57:132-7.

Hanson BR, May DM. 2004. Effect of subsurface drip irrigation on processing tomato yield, water table depth, soil salinity and profitability. Ag Water Mgt 68:1-17.

Hanson BR, May DM. 2006. New crop coefficients developed for high-yield processing tomatoes. Cal Ag 60:95-9.

Hanson BR, May DM. 2007. The effect of drip line placement on yield and quality of drip-irrigated processing tomatoes. Irrig Drain Sys 21:109-18.

Hanson BR, May DM, SchwankI L. 2003. Effect of irrigation frequency of subsurface drip irrigated vegetables. Hort Technol 13(1):115-20.

Hanson BR, Šimůnek J, Hopmans JW. 2006. Numerical modeling of urea-ammonium-nitrate fertigation under microirrigation. Ag Water Mgt

Hanson BR, Šimůnek J, Hopmans JW. 2008. Leaching with subsurface drip irrigation under saline, shallow groundwater conditions. Vad Zone J 7(2):810-8.

Maas EV, Grattan SR. 1999. Crop yields as affected by salinity. In: Skaggs RW, van Schilfgaarde J (eds.) Agricultural Drainage. Agron Monograph 38. ASA CSSA, SSA, Madison, WI. p 55-108.

Schoups G, Hopmans JW, Young CA, et al. 2005 Sustainability of irrigated agriculture in the San Joaquin Valley, California. PNAS 102(43):15352-6.

Šimůnek J, Šejna M, van Genuchten MTh. 1999. The HYDRUS-2D Software Package for Simulating Two-dimensional Movement of Water, Heat and Multiple Solutes in Variably Saturated Media. Ver. 2.0, IGWMD-TPS-53. International Groundwater Modeling Center, Colorado School of Mines, Golden, CO. 251 p

Styles S, Oster JD, Bernaxconi P, et al. 1997. Demonstration of emerging technologies. In: Guitjens J, Dudley L (eds.). Agroecosystems: Sources, Control and Remediation. AAAS, Pacific Division, San Francisco, CA. p 183-206.

Wallender WW, Grimes DW, Henderson DW, et al. 1979. Estimating the contribution of a perched water table to the seasonal evapotranspiration of cotton. Agron J 71:1056-60.

Westlands Water District. 2009. 2008 Crop Acreage Report. www.westlandswater.org. $86: 102-13$ 